\title{
A New Strategic Proposal of Change in the Conversation Program of the School of Modern Languages at the University of Costa Rica: English for Specific Purposes Courses
}

Walter Araya Garita

Escuela de Lenguas Modernas

Universidad de Costa Rica

\begin{abstract}
This article is the result of a research project on a proposal of change in the academic offer of the Conversation Courses of the School of Modern Languages at the University of Costa Rica. This study shows the results obtained through a questionnaire given to the advanced students of the program and different opinions of people who are related to the process of teaching English as a second or foreign language. Finally, some recommendations will be given to the administration of the program to put the proposal into practice.
\end{abstract}

Key words: organizational change, english for specific purposes, teaching english, english courses

\section{Resumen}

Este artículo es el resultado de una investigación sobre una propuesta de cambio en la gestión académica del Programa de Cursos de Conversación de la Escuela de Lenguas Modernas de la Universidad de Costa Rica. Este estudio comprende los resultados de un instrumento administrado a los estudiantes del último nivel en el idioma inglés y opiniones de diferentes personas involucradas en la enseñanza de este idioma. Por último, se hace una serie de recomendaciones a la administración del programa para llevar a cabo la propuesta de cambio en la institución.

Palabras claves: cambio organizacional, inglés con fines específicos, enseñanza del inglés, cursos de inglés 


\section{Introduction}

$\mathrm{D}$ uring the last decades, it has been observed in the media that learning English has become a must for Costa Ricans. As a consequence, a new growing market has expanded. Private and public institutions are part of it. Some of them are more than twenty years but most of them are relatively new. The School of Modern Languages of the University of Costa Rica (UCR), for example, is an option students have to learn a foreign language in the country.

Currently, this School offers two majors; one is in English and the other one is in French. Additionally, there are other programs such as English for Specific Purposes (ESP) for UCR learners, and two B.A. in English and French (offered through an open system in which students do not attend regular classes) and a Program of English Conversation Courses. The present research project deals precisely with this Program. The main objective is to demonstrate the need to implement new ESP courses for students who already completed the whole program, which implies a change in its academic offer. This new proposal will give a more competitive position to the English Conversation Program in the national market of language teaching. On the other hand, students will have more possibilities to continue learning and improving their level of competence in the language.

\section{Review of Literature}

The review of literature must be addressed into two different ways: the context of English for Specific Purposes (ESP) and the concept of organizational change.

English for Specific Purposes (ESP) is a growing language field in English Language Teaching (ELT). DudleyEvans and St John (1998) believe that the main concerns of ESP have always been, and remain, with needs analysis, texts analysis, and preparing learners to communicate effectively in the tasks prescribed by their study or work situation. In the Program of English Conversation Courses of the School of Modern Languages, these concerns are also part of an analysis to offer new courses. Hutchinson and Waters (1987) comment "tell what you need English for and I will tell you the English that you need" (p. 8). In other words, the English needed by a particular group of learners could be analyzing the linguistic characteristics of their specialist area of work.

Dudley-Evans and St John (1998) add that a definition of ESP should reflect the fact that much ESP teaching, especially where it is specifically linked to a particular profession or discipline, makes use of a methodology that differs from the used in General Purpose English teaching (p.4), which is the approach used in the English courses by the Conversation Program.

ESP is divided into two branches. The first one is English for Academic Purposes (EAP) and English for Occupational Purposes (EOP). According to Dudley-Evans and St John (1998), these distinctions are very important as they will affect the degree of specificity that is appropriate to a course. In this sense the teacher is not only an instructor but becomes a course designer and material provider, collaborator, researcher and evaluator. 
Hutchinson and Waters (1987) add that ESP must be seen as an approach and nor as a product. ESP is not a particular kind of language or methodology, not does it consist of a particular type of teaching material (p.19).

On the other hand, all organizations must create strategic plans to achieve their goals. In this sense, changing and planning have to be measured based on the strategy that the institutions have in short or long terms. Furthermore, the size of the institution must be taken into consideration when planning changes.

It is also essential to know the mission of the organizations every time one plans to implement strategic projects in order to work around it. Pérez (2012) mentions that an organization that continues satisfying people's needs is still able to obtain even more resources through time and in the future will have more value, just as its abilities and capacity increase. Organizations must adapt themselves to the changing environment to satisfy those needs previously mentioned. Pérez (2012) continues exposing that those organizations which succeed are the ones that have a correct reading of the changes and know how to adopt them. In addition, these organizations know how to address new challenges that could come up. Knowing that we live in a changing world, this premise is even more important.

Changes could be categorized in different ranges or areas of the organization. Acosta, (2002), comments that changes are produced in functional areas, in business units, in some specific procedures and even at the organization level. However, changes must not be very different among them. On the contrary, each changing proposal is created based on the perspective one sees the organizations and consequently they are affected.

On the contrary, other authors agree about a total change. For instance, Katz and Kahn (1983) affirm that the organization is an open system and in that sense every organizational change is not only an answer for the external changes but also an internal arrangement. Thus, it is not about implementing an isolated action since a single change in a specific unit of the organization can affect the whole organization. Gordon (1999) also agrees with the previous authors. He thinks that what it changes in the organization is the "whole" organization and not a single part.

From this perspective, Pérez (2012) enlists the locations of emphasis where one can control the organizational change. They are as follows: formal structure of the organization, technology, procedures, products and services, organizational culture and human behavior. In this scenario, this paper presents the project of changing the products and services that the Conversational English Program of the School of Modern Languages at the University of Costa Rica offers.

Some people may not believe that products and services are not organizational changes themselves. However, Acosta (2002) thinks that it is important to take into account changes that are produced in products and in services that organizations need. It is impossible not to recognize them, if there is a variation in the way to elaborate or to deliver these products that are generally related to productive and administrative procedures, to the culture of 
production and service and to changes in the attitudes of people who participate in the transformation of raw material or in the products (p.13).

The plan of expanding the academic offer of the Conversation English Program is a clear example of organizational change from the perspective that administrative procedures have to be adapted as the surrounding context changes. Consequently, training teachers in ESP becomes a must. The culture of the organization may change since some teachers have to be instructed in this growing field of language teaching. One example is that that they have to modify their way of thinking in the sense that they not only have to work in classrooms but they have to go to companies to get to know as much as they can from their possible students.

Furthermore, the Conversation English Program also has to change its products based on the needs of its students. Acosta (2002) mentions that organizations have to take into account a quantitative growth in the infrastructure but also in the quality of the product, which has to be programmed. In other words, organizations change to answer the internal demands that affect their own evolution and entropy, and also to face the external forces related to their own growth and to the market of the organization.

Another important issue organizations must take into account is their own re-invention to develop new products or services as part of the organizational change. Barba (2000) enlists different reasons why organizations have to change:

- Developing new products

- New management tendencies in the organizations
- Pressures from the environment

- Financial problems

- Re-arrangement from a new scenario created by the competence

- Strategic alliances

- Implementation of ITs

- Worldwide policies

- State investment

- Global competence

- Natural disasters

Organizations use changes as a better way to deal with the varying scenario they face day after day, as an improvement in their capacity to take advantage of the opportunities of the environment, and as a way to find the correct track during hard times.

Changes are not simple when one takes into account the factors previously mentioned. External and internal pressures can exist. Gordon (1997) believes that resistance to change is produced by lack of knowledge and beliefs of some members of the organization, lack of exposure to specific information about the process of change, lack of perception on the need for a change, generation of attitudes against the proposal, generation of menaces towards the experience, CEOs, and bureaucracy, among others (p.670).

Organizations always find internal and external or individual and organizational sources that are reluctant to processes of change. Robbins (1999) includes six different aspects, which can reduce that resistance, which are: education and communication, participation, facilitation, encouragement, negation, and manipulation (p.636).

Change is a normal stage in the cycle of life of any organization as it is mentioned by Gordon (1997). The environment changes, but it is part 
of a major system called society. And within this evolution, organizations change to avoid their collapse. In other words, it is imperative that organizations change. If they do not do it, they will not survive. Robbins (1999) affirms that norms and values must be respected to give an additional value to that change. Some of these values, for instance, are respect for people, trust and support, equality of power, and confrontation in the sense that problems cannot be avoided.

\section{General Objective}

To highlight the importance of implementing an advanced English program of ESP courses that complement the Conversation Program of the School of Modern Languages of the University of Costa Rica.

\section{Specific Objectives}

- To describe the existing courses of the Conversation English Program at UCR.

- To compare the UCR with other two Conversation Programs offered in the country.

- To know the needs of current students of the program for learning English.

- To design a proposal to implement ESP courses in the Conversation Program of the UCR.

\section{Methodology}

The methodology to develop the current research project includes a mixture of a qualitative and quantitative process. It has been decided to work with both approaches, since for some parts of the process, the subjective point of view is the source to build knowledge on a hermeneutic base. This subjective information comes up from the experience of the researcher, the answers of the Coordinator of the English Conversation Program and the president of the organization of a company called ESP that focuses on teaching English for specific purposes. (See appendix 1 and 2). It also comes from the analyses of different materials like web sites and brochures of other language institutions.

On the other hand, quantitative research is also taken into consideration to develop this project. Cascant and Hueso (2012) say that this kind of research is based on numbers, in the use of statistic techniques to know certain aspects of interest about the population that is under study. Three key elements must be identified since the very beginning in this kind of research. These authors think that a more important role should be given to the population, to the subject of study and to the sample. The first one, in other words, the population, is the sum of subjects that one uses to try to answer the hypothesis. The subject of study is the person from whom we try to find the information and the sample is just part of the population.

As it was mentioned before, the quantitative research is based on numbers. According to Cascant and Hueso (2012), numbers and statistics play an important role. These two aspects are very important since they help to identify and prioritize areas of attention, analyze evaluations, set objectives, evaluate indicators and know the impact. 
In this article, some of the objectives will be measured through indicators such as the new proposal, new courses, and the amount of new students among others. In addition, a sample of the population (students of the program) was also selected to obtain specific information.

\section{Participants}

Participants in this study were the coordinator of the Conversation Program of the School of Modern Languages of the University of Costa Rica, and the president of the organization of a program called ESP that focuses on teaching English for specific purposes. Finally, 10 students out of 15 , from the 12th level of the Conversation Program were contacted to complete a questionnaire.

\section{Materials}

Three different instruments were created to obtained information (see appendixes 1,2 and 3). The first instrument seeks to obtain general information about the Conversation Program of the School of Modern Languages of the University of Costa Rica from its Coordinator. The questionnaire includes 5 open questions about the registration, profile of students, academic offer, unmet demand, competence from other language teaching institutions, and profile of teachers they hire.

The second instrument aims to obtain general information about a company whose strength is to design and teach ESP courses addressed to a very specific population of students. It consists of six questions about the profile of the company, its experience, type of students, how they contact potential students, the course design, and the profile of their students.

Finally, an instrument was used to get general information from the students of level 12 of the Conversation Program. It consists of 8 items which include age, gender, major or career, frequency of the usage of the English language in their lives or jobs, reasons to study English, time they have received formal instruction in English, and possible desire they have to continue learning English.

\section{Procedure}

The first step was the review of literature related to the research topic. Based on this information, the objectives were created. The other step was to create the different instruments to obtain information. Then participants were contacted for an interview. The Coordinator of the Conversation Program was also contacted to obtain the authorization to visit the two groups of level 12 to give the questionnaire to the students. In addition, there was an analysis of different printed and on line information about other language institutions. Finally, all the data was analyzed to transform it into information to discuss the results.

\section{Results}

The Conversation Program of the School of Modern Languages started in 1995. By that time, English and French were the only two languages 
taught. There were only basic languages courses. Nowadays students have more possibilities to register new options in Portuguese, Italian, Japanese, German, Chinese, and Russian.

Courses are scheduled every two or three months. The number of levels offered are based on the demand the language has. This situation is illustrated in table 1.

Table 1

Academic Offer by Language

\begin{tabular}{lc}
\hline \multicolumn{1}{c}{ Language } & Levels \\
\hline English & 12 \\
French & 9 \\
Chinese & 8 \\
Italian & 5 \\
Portuguese & 5 \\
Russian & 5 \\
German & 5 \\
Japanese & 4 \\
\hline
\end{tabular}

Source: http://lenguasmodernas.ucr.ac.cr/?pag=26

There is no entrance test to register in the program. Any person can enroll in the first level of any language course offered. Students can perfectly be true beginners. On the other hand, English learning students, who are in level 12, are expected to be high intermediate. In other words, students should communicate in oral and written form. This last level (12) has been designed to train students in oral communication. Students also have to use the different knowledge learned during the previous eleven levels. The different activities for writing, reading, speaking, and listening skills are integrated into the contents. Each level is six hours per week during weekdays, and four hours a week when they are offered Fridays and Saturdays. In the first case, each level is two months and in the second case, it is three months.

As it was mentioned before, the contents for each level are current issues used in general English teaching. For example, students have to deal with general topics such as: "crime and criminals" in level 12. They also have the possibility to choose among the following options: "technology", or "ethical issues" like: abortion, in vitro fertilization, divorce, sexual preferences, drug legalization, and discrimination.

Another important aspect that has to be mentioned is the facilities the Program uses. The Program utilizes the structure of the College of Liberal Arts at the University of Costa Rica and a building called the "La Casa de Idiomas", which was bought by the Program. For the courses offered trimonthly, the schedule is from 14:00 to 17:00 In the College of Liberal Arts, the courses are offered only at night (from 18:00 to 21:00), and only 30\% of the total of the classrooms of the building can be used by the program since the administration needs all the classrooms for regular courses of the University of Costa Rica. This situation has become a problem.

The quarterly courses are Fridays from 17:00 to 21:00, Saturdays from 8:00 to $12: 00$ and from 13:00 to 17:00. There are no serious problems of classroom availability for this format since on Saturdays the Program has the possibility to use all the building of the College of Liberal Arts and "La Casa de Idiomas".

Another important element to take into consideration is that the Program does not accept students under 15 years old since companies do not cover this population in case of any accident. 
In regards to the Program's population of students, it is necessary to say that it is heterogeneous. They are university students, professionals, young people with different technical skills, unemployed people, and housewives among others. Even though there are no formal studies about the current situation of the students of the Program, the input that the teachers of the Program has given about them helps to come out with these conclusions. In addition, the experience of the researcher of this paper, who has also worked in the Program, contributes to build the profile previously mentioned.

The fees are US $\$ 130$ for those students who prefer the courses which last 3 months, and US\$ 123 for the two months level course. In this moment, the total number of students enrolled in the program is approximately 3000 (three thousand).

As it was mentioned before, the Conversation English Program is an extension project of the School of Modern Languages at the University of Costa Rica. It is 24 years old. The objective of the Program is to offer to Costa Rican society the opportunity to learn, improve and master foreign languages in order to communicate effectively. At the same time, it is expected that students can develop some linguistics competence in reading, writing, listening, and speaking.

This program is considered successful. The funds that it produces are administered by the Foundation for Research of the University of Costa Rica (FUNDEVI). As it is observed in the following figure, the School of Modern Languages is number four among different projects that generate more financial resources to the University.
During 24 years, this Program has never closed because of lack of students. On the contrary, there are always more and more students who want to join it and they cannot because there is no space for them. This is happening in a moment when there are many new private language institutions, which also open new branches all over Costa Rica. One example is the Centro Cultural Constarricense Norteamericano, whose fee is twice as expensive compared to the UCR program. Another institution that gives this service is the Instituto Tecnológico de Costa Rica by its foundation (FUNDATEC). They also offer English courses and the fee is approximately US\$ 160 every two months, which is more expensive than the UCR Program.

According to the information given by the Coordinator of the Program, this situation is not a threat to them. On the contrary, historically, the demands of new students have been steady. The problem to continue growing and opening new groups has to do with infrastructure. The facilities this program uses belong to the University of Costa Rica, and only a few rooms during the semester are assigned to the Program. The other place where the courses are taught is the Casa de Idiomas, but this is a very small building with limited rooms.

The administrative structure of the English Conversation Program is not complex. A professor of the School of Modern Languages coordinates the Program. All teachers of the Program are graduated from the BA in English or French. They are also graduate students. They are approximately 20 administrative employees and 45 language teachers. 
Figure 1

Projects that Generate Funds to the University of Costa Rica

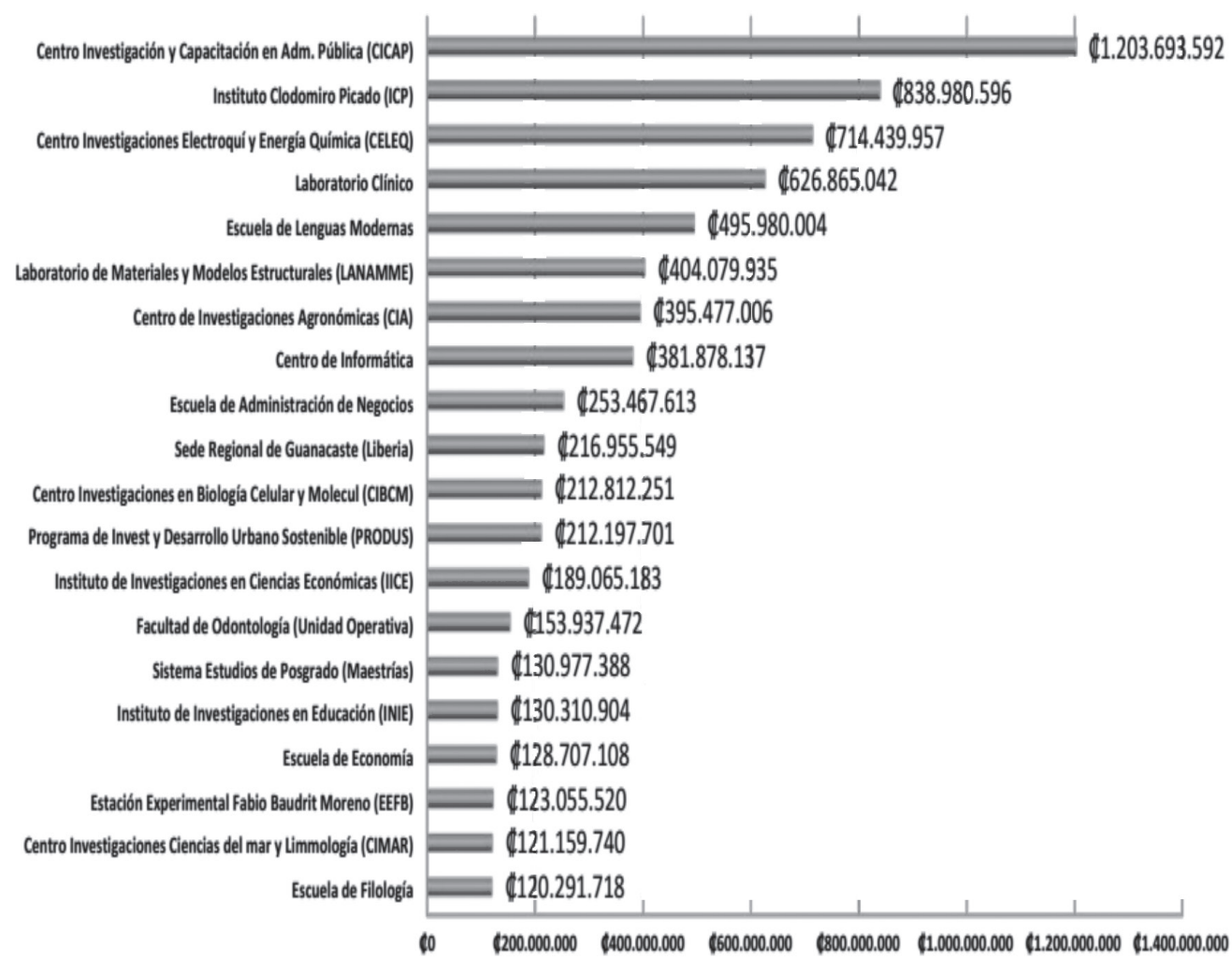

Source: FUNDEVI

As it was mentioned before, courses are focused in teaching general English, or introductory courses. People who conclude this program are supposed to be high intermediate users of the language. However, nowadays the tendency to learn and teach English goes beyond than dealing with general English. Hernández (2007) states that "the priority in this moment is the English language which has become in a second language", and this new tendency must be reflected in teaching English for Specific Purposes. Likewise, this new approach is essential to guarantee good students' performance in a second language. Marín (2004) agrees with Hernández, since he thinks that students must be the starting point to teach a second language. In other words, all decisions regarding contents and approaches to use in the language process must be based on the reason(s) why the student wants to learn. These characteristics, in spite of the fact they are not explicit in Marín's proposal, can be exemplified in translation. This is an indispensable tool for learners. Nowadays, Hernández confirms that even though translation is not the only tool, teachers must give students other tools to face, in a better way, the current global scenario and to find better job opportunities. 
Hernández (2007) continues expressing that organizations need employees that speak, read and write, at least, in a foreign language, mainly English but also Portuguese. This means that people must have an intermediate linguistic level, in that foreign language, in which they can perform successfully in different fields such as costumer service, accountability, business administration, system engineering, software engineering, industrial engineering, and finances among others. Also, it has been recently observed in the media, that new fields, such as health tourism, have grown in this country. This means that doctors, nurses, dentists, nutritionists, just to mention some examples, are in the need to learn a foreign language.

The current study presents a profile of the students who are about to finish level 12 of the English Conversational Program. The idea was to explore their needs and likes to continue learning English. An instrument (See appendix 3) was given to them. Only ten students out of fifteen filled it in.

Their ages vary from 22 to 35 years old. Six of them are female students. All of them work and have a different career, which confirms that this is a heterogeneous population. They are: computer engineer, industrial engineer, philologist, pharmacist, architect, costumer service officer, professional in public relations, school teacher, musician, and business administrator.

Another important aspect is that 8 of them need to use English in their jobs. They use this language to sing songs, read music, teach children some vocabulary, communicate with clients, translate documents, talk to different people, and read technical documents.
The answers also show that all of them have studied English for more than two years (length of the English Conversational Program). The average is from 3 to 4 years of learning experience. They were asked why the study English. Their answers are similar since they said:

- To have more curriculum

- To have more access to information

- To develop English oral skills

- To earn more

- To have a diploma

- To apply for a better job

- English helps you in your job

- To speak fluently

- Just to learn a second language

Finally, they were asked if they wanted to continue in the program and what were their needs. The results show that more than $50 \%$ of the students answered affirmatively. Their needs are:

- More conversation

- Something to improve my current English level

- Technical English

- To apply for standardized tests such as TOEIC and TOELF.

Students were also asked if they wanted to continue studying. It is clear that this specific population agrees to register in an advanced English program to develop even more what they have learned so far. From this scenario, one can conclude that the English Conversational Program can attend these students' needs.

\section{Proposal}

The objective of the present study is to show that a new ESP program 
can open next year in the English Conversational Program of the School of Modern Languages . During the first stage, the program will be offered to groups of professionals arranged by areas such as engineering, economy, and health among others. The groups are from 6 to10 people. These courses will be offered every two months and they are four levels. They will concentrate on one macro-skill by level: reading, writing, listening, and speaking, based on specific context depending on students' careers. The second stage is that the program can give ESP courses but to no more than two students per group. These courses will be offered every three months. The first month is to prepare the course in the work place of these 2 students. During the other two months, the teacher meets the students. In total, there are 3 levels.

The fees for this new program would be US $\$ 200$ for the 4 courses of the first year and US $\$ 400$ for the more specific courses, the ones offered in the second year. These fees are based on the previous information obtained from other institutions that offer general English courses and ESP. Besides, students would have to buy the materials for the courses of the first year and the Program will create authentic materials for the courses of the second year.

The new Advanced English Program proposed in this article includes 7 levels that would take two years for students to complete. The courses will be given in small classrooms. This will overcome the existing limitation of lack of classrooms. These small classrooms are the ones that the program cannot use nowadays since current groups are more than 20 students. On the other hand, the teachers that cur- rently work in the program would be the instructors of this new program. It is important to mention that this advanced program would be a new option for learners who conclude the English Conversational Program.

In Costa Rica, there is only one single institution that offers ESP courses. Its name is ESP. This organization has been in the market for 15 years. According to one of its CEOs, they do not need to advertise this organization since students look for it by themselves, which demonstrates that there is a potential market. Their instructors go to the students' office to teach them. There are not regular classes,

The teachers of the ESP Program design the courses they offer. What they do is to concentrate on students' needs based on the information they collect at their work place. Consequently, if the course is two months long, the first month is to collect and prepare the course and during the second month the teacher meets the student in individual sessions that are from 2 to 10 hours per week. It depends on what the student wants and needs. The fees they have to pay range from US $\$ 500$ to US\$ 1500. Their instructors are graduate students from the MA Program in the University of Costa Rica.

\section{Conclusions}

From this analyzed scenario, one can come out with the following conclusions:

- The University of Costa Rica, through its English Conversational Program, is an institution that has been in the market for more than 20 years. This 
shows its solidity and has demonstrated to be a successful program.

- The English Conversational Program has a positive position in the market. During its 20 years, there are always students who want to enroll the programs and the other English teaching institutions do not represent a threat to the program. Finally, the fees of the Conversation Programs are the cheapest ones in the market.

- The University of Costa Rica has no infrastructure for the Conversation Program to continue growing, but has the possibility to diversify its products. In other words, infrastructure has been the most serious weakness found in this project. This limitation has not allowed the English Conversation Program to open more groups for the different levels. The Program can take advantage of the small classrooms (they are for 10 people) in the "La casa de Idiomas" by diversifying the academic offer. Besides, the last courses (ESP) will be offered in the students' offices, which would be a positive learning experience for them.

- Current students mentioned they have different needs to continue learning English. They said they want more technical skills. This characteristic makes them the target population.

- The University of Costa Rica (UCR) has qualified workforce to teach this new advanced English Program, since ESP company even uses graduate students from UCR in its organization.

- The University of Costa Rica does not have to invest extensively to put into practice this proposal. On the contrary, the main constraint that historically has been, the lack of classrooms to offer courses, will be overcome teaching small groups and teaching in the students' work place.

- Other English teaching institutions do not represent a threat for the English Conversational Program. There are always new students who want to enroll this Program.

\section{Recommendations}

The first stage to put into practice this proposal is to formalize it in the Office of Social Extension of the University of Costa Rica. Another strategic stage in this process is to have the support of the School of Modern Languages through its Social Extension Committee.

Another important strategy is to communicate to the graduated students of the program about the new courses that are about to be offered. This has to be done since August to start January of the next year. The English Conversational Program already has this information in its databases.

The English Conversational Program has to work together with the TESOL Master's Program of the University of Costa Rica. The idea is that these graduate students can use the English Conversational Program for their ESP course. Definitely this is a two-way benefit.

\section{Bibliography}

Acosta, C. (2002). Cuatro preguntas para iniciarse en el cambio organizacional. Revista Colombiana de Psicología, 1, 9-24. 
Barba, A. (2002). Cambio organizacional y cambio en los paradigmas de la administración. Itzapalapa, 48, 11-34.

Dudley, E., \& St. John, M. (1998). Developments in English for Specific Purposes: A Multidisciplinary Approach. USA: Cambridge University Press.

Gordón, J. (1997). Comportamiento organizacional. México: Prentice Hall.

Hernández Herrero, A. (2007). El inglés en Costa Rica: requisito indispensable en un mundo globalizado. Actualidades Investigativas en Educación, 8, 1-23. Recuperadode http://revista.inie.ucr.ac.cr/ediciones/controlador/Article/accion/ show/articulo/el-ingles-en-costarica-requisito-indispensable-en-unmundo-globalizado.html

Hutchinson, T. \& Waters, A. (1987). English for Specific Purposes. USA: Cambridge University Press.

Katz, D. \& Kahn, D. (1983). Psicología social de las organizaciones. México: Trillas.

Marín-Arroyo, E. (2004). La enseñanza del inglés en Costa Rica en el siglo XIX: una respuesta al modelo económico. Revista Comunicación, 25, 47-55.

Robbins, S. (1999). Comportamiento organizacional. México: Prentice Hall.

Pérez, J. (1 de diciembre 2012). Reflexiones sobre la gestión del cambio y liderazgo. Manuscrito no publicado.

\section{APPENDIX}

\section{Appendix 1}

Entrevista a la Coordinadora del Programa de Cursos de Conversación
El presente cuestionario es parte de una investigación para el curso "PF4108 Cambio Organizacional" del Programa de Posgrado en Administración Universitaria. Las respuestas que usted de serán analizadas de manera general. Muchas gracias por su colaboración.

1. ¿Cuáles personas pueden matricular los cursos de conversación?

2. ¿Conocen ustedes el perfil de los estudiantes del programa?

¿Por qué disminuye la oferta académica en otros idiomas?

3. ¿Alguna vez no ha tenido demanda o la demanda en los cupos de los programas ha sido muy poca?

4. ¿Qué tan fuerte es la competencia? ¿La considera una amenaza?

5. ¿Cuál es el perfil del docente que ustedes contratan?

\section{Appendix 2}

\section{Entrevista a la Coordinadora del Programa ESP}

El presente cuestionario es parte de una investigación para el curso "PF4108 Cambio Organizacional" del Programa de Posgrado en Administración Universitaria. Las respuestas que usted de serán analizadas de manera general. Muchas gracias por su colaboración.

1. ¿Qué es ESP?

2. ¿Desde hacen cuanto trabaja esta compañía?

3. ¿Cómo consiguen sus clientes?

4. ¿Cómo diseñan sus cursos?

5. ¿Cuál es el perfil del docente que ustedes contratan? 


\section{Appendix 3}

Instrumento para estudiantes

El presente cuestionario es parte de una investigación para el curso “ PF - 4108 Cambio Organizacional “ del Programa de Posgrado en Administración Universitaria. Las respuestas que usted de serán analizadas de manera general. Muchas gracias por su colaboración.

1. Nivel en el que está matriculado:

2. Edad:

3. Género:

4. Ocupación:
5. ¿Requiere del idioma inglés en su trabajo?

Sí No

$\mathrm{Si}$ su respuesta es afirmativa indique qué tipo de destrezas utiliza

5. ¿Cuáles son las razones por las que estudia inglés?

8. ¿Por cuánto tiempo ha estudiado inglés? Incluya otras instituciones si fuera el caso

9. ¿Desea seguir estudiando inglés una vez finalizado el Programa de Cursos de Conversación de la UCR? Sí No

$\mathrm{Si}$ su respuesta es afirmativa indique que tipo de curso le gustaría matricular 